CASE REPORT

\title{
Kleine-Levin and Munchausen syndromes in a patient with recurrent acromegaly
}

Kerstin Jungheim, Klaus Badenhoop, Oliver G Ottmann ${ }^{1}$ and Klaus H Usadel

Departments of Medicine I and ${ }^{1}$ III, Klinikum of the J W Goethe University, Frankfurt, Germany

(Correspondence should be addressed to K Jungheim, Department of Medicine I, J W Goethe University, Theodor-Stern-Kai 7, 60590 Frankfurt am Main, Germany)

\begin{abstract}
Hypothalamic disease often affects the patients' personality and this also applies to pituitary tumors with suprasellar extension.

We report on a patient with a 12-year history of recurrent acromegaly, treated with three transphenoidal operations, single field radiation therapy and bromocriptine/octreotide administration. During the course of follow-up she presented with self-inflicted anemia and Kleine-Levin syndrome (hypersomnia, hyperphagia and hypersexuality). Furthermore, she developed post-radiation necrosis within the right temporal lobe.

Whether her neurological and personality disorders result - at least partially - from the acromegaly or the temporal lobe necrosis remains unclear.
\end{abstract}

European Journal of Endocrinology 140 140-142

\section{Introduction}

Munchausen syndrome was first described in 1951 by Asher (1) as an acute illness with a dramatically false, yet plausible history. Eventually, the term was extended to several self-inflicted illnesses. The symptoms are manifold, extending from pain in $75 \%$ of cases that seem to make surgical intervention necessary, to coagulopathies after intake of anticoagulants, irondeficient anemia after phlebotomy, urogenital, oral or rectal manipulation (2), self-induced infections (3) and hypoglycemia (4).

The Kleine-Levin syndrome is characterized by attacks of the triad hypersomnia, vegetative disturbances such as hyperphagia and hypersexuality, psychopathological changes in the level of consciousness and emotional life which lasts for $1-3$ weeks. Most commonly it is a disease of young men, but also elderly people and women can be affected (5). Etiology and pathogenesis are unknown, but hypothalamic dysfunction seems to be the most likely.

\section{Case report}

A 30-year-old white female with a 12-year history of acromegaly presented for evaluation of anemia. Acromegaly had been diagnosed in 1983 when the patient was 21 years old. Treatment consisted of three consecutive transsphenoidal operations in 1983,
1989, and 1991 with incomplete resections of a growth hormone (GH)-secreting adenoma. In 1992 she underwent radiation therapy of the pituitary after persistence of elevated $\mathrm{GH}$ levels and symptoms of acromegaly. Except for a partial bitemporal hemianopsia, there were no neurological symptoms. Treatment consisted of $5 \mathrm{mg}$ bromocriptine per day since 1989 and $600 \mu \mathrm{g}$ s.c. tid octreotide, the somatostatin analog, since 1991. The resulting secondary hypopituitarism was substituted adequately with $37.5 \mathrm{mg}$ cortisone acetate and $150 \mu \mathrm{g}$ L-thyroxine per day.

During the two years prior to admission she complained of intermittent chest pain and frequent headaches, which ensued a self-medication of analgesics over the last years (aspirin and ibuprofen, doses of $2 \mathrm{~g} /$ day and $1.5 \mathrm{~g} /$ day respectively). At this time, she gained $20 \mathrm{~kg}$ in weight up to $96 \mathrm{~kg}$. The patient was single, lived with her parents and worked as an electrical communication engineer. She had broken up with her boyfriend two years previously. During a routine follow-up, paleness, weakness and a hemoglobin concentration of $6.2 \mathrm{~g} / \mathrm{dl}$ were noticed. The patient was admitted to the University Hospital, Frankfurt. The physical examination revealed obesity and typical features of acromegaly. Blood pressure was 100/ $60 \mathrm{mmHg}$. Values for adrenocorticotropin $(24.4 \mathrm{pg} / \mathrm{ml}$, normal $<80 \mathrm{pg} / \mathrm{ml})$, luteinizing hormone $(2.5 \mathrm{mIU} / \mathrm{ml}$, normal $1-25 \mathrm{mIU} / \mathrm{ml})$, follicle-stimulating hormone $(4.8 \mathrm{mIU} / \mathrm{ml}$, normal $3-20 \mathrm{mIU} / \mathrm{ml})$, prolactin 
$(1.6 \mathrm{ng} / \mathrm{ml}$, normal $<16 \mathrm{ng} / \mathrm{ml})$, thyroxine $(10 \mu \mathrm{g} / \mathrm{dl}$, normal $4.5-12.5 \mu \mathrm{g} / \mathrm{dl})$, tri-iodothyronine $(140 \mathrm{ng} / \mathrm{dl}$, normal $70-190 \mathrm{ng} / \mathrm{dl})$ and cortisol $(5.8 \mu \mathrm{g} / \mathrm{dl}$, normal $4.0-23 \mu \mathrm{g} / \mathrm{dl})$ were normal or slightly decreased, thyrotropin was decreased $(0.1 \mu \mathrm{U} / \mathrm{ml}$, normal $0.3-$ $4.5 \mu \mathrm{U} / \mathrm{ml})$, GH $(9.2 \mu \mathrm{g} / \mathrm{l}$, normal $<5 \mu \mathrm{g} / \mathrm{l})$ and insulinlike growth factor-I $(906 \mu \mathrm{g} / \mathrm{l}$, normal 123-463 $\mu \mathrm{g} / \mathrm{l})$ were increased; $\mathrm{GH}$ was not suppressed by oral glucose load with $50 \mathrm{~g}(0 \mathrm{~min}=9.2 \mathrm{ng} / \mathrm{ml}, 30 \mathrm{~min}=$ $7.4 \mathrm{ng} / \mathrm{ml}, \quad 60 \mathrm{~min}=7.0 \mathrm{ng} / \mathrm{ml}, \quad 120 \mathrm{~min}=6.5 \mathrm{ng} / \mathrm{ml}$, normal $<1 \mathrm{ng} / \mathrm{ml})$. The anemia was microcytic and normochromic, the hematocrit was $19 \%$ and the mean corpuscular hemoglobin concentration $20 \mathrm{~g} / \mathrm{dl}$. Iron levels were decreased (normal levels in brackets): iron, $34 \mu \mathrm{g} / \mathrm{dl}(49-194 \mu \mathrm{g} / \mathrm{dl})$, ferritin, $5 \mu \mathrm{g} / \mathrm{l}(22-112 \mu \mathrm{g} / \mathrm{l})$, vitamin B12, $223 \mathrm{pg} / \mathrm{ml}(220-1000 \mathrm{pg} / \mathrm{ml})$. Tests for occult blood in the stools were negative, as were an ultrasound examination of the abdomen and a gastroscopy. The patient received 4 units of packed red blood cells, to reach a hemoglobin concentration of $10 \mathrm{~g} / \mathrm{dl}$. After ineffective oral iron administration, an intravenous substitution was begun. She frequently fell asleep, up to two or three times a day for up to $4 \mathrm{~h}$ and could not be woken up. An EEG showed no abnormalities. An MRI of the head revealed the previously described residual pituitary tumor adhering to the right carotid artery, as well as a radiation necrosis within the right temporal lobe. After repeated questioning the patient admitted suffering from sleeping attacks of up to $20 \mathrm{~h}$ a day, and having a ravenous appetite and increased libido for several years. During the course of the hospitalization a continuous decrease of the hemoglobin concentration was noticed, which made frequent blood transfusions necessary. On average $2000 \mathrm{ml}$ blood were transfused per month.

Repeated gastroscopies, colonoscopies and radiological examinations of the small and large bowel were normal. A neurologist made the diagnosis of Kleine-Levin syndrome (hypersomnia, hyperphagia and hypersexuality). Therapy with clomipramin was begun and the patient was discharged. The cause of anemia had not been found, and oral iron substitution continued. Over the next weeks and months, she required as many as two transfusions per week and had to be readmitted to the hospital up to six times in one year.

Laboratory evaluation consistently revealed low hemoglobin $(5.5 \mathrm{~g} / \mathrm{dl})$ and low ferritin $(1-9 \mu \mathrm{g} / \mathrm{l})$ despite oral iron substitution therapy and blood transfusions. The gynecological examination was non-diagnostic. An erythrocyte scan revealed no abnormalities. There were no signs of hemolysis or hemoglobinopathy.

In June 1994, the patient was readmitted because of numbness in the legs and arms, left-sided impairment of the hearing, intermittent epistaxis, abdominal pain and diarrhea. Physical examination revealed multiple puncture sites above the ankles in both saphenous veins. Suspecting a factitious disorder, she was referred to a psychiatrist. The evaluation concluded that the patient appeared suspicious but not suicidal. She denied any self-inflicted disease and refused psychotherapy, leaving the hospital the same day.

After 6 weeks she was seen again complaining of all previously stated symptoms. Again multiple sites of venopuncture along the saphenous veins were visible. After blood transfusion, she agreed to undergo psychotherapy. She always denied having performed phlebotomy. While in psychiatric care, she repeatedly needed blood transfusions. It became known by chance through a statement of a friend that she had been sexually abused by an uncle as a child.

\section{Discussion}

This case report describes a course of persistent acromegaly after three pituitary operations and pituitary radiation despite bromocriptine/octreotide therapy.

This case was complicated by anemia caused by repeated phlebotomies due to Munchausen syndrome. Additionally, the patient developed Kleine-Levin syndrome, diagnosed 10 months after pituitary single field radiation and concomitant with a right temporal lobe necrosis. Apart from sleep attacks, hypersexuality and hyperphagia no other neurological symptoms occurred. Although we cannot relate Kleine-Levin syndrome to post-radiation necrosis, chronic active acromegaly may have caused or contributed to its development, because patients with GH-secreting adenomas often suffer from behavioral disturbances as well as sleeping and eating abnormalities.

Little is known about the psychopathology of Munchausen syndrome and no association has been reported with pituitary disease so far. As reported by different authors $(6,7)$ sexual abuse such as rape is known to trigger psychopathological behavior consistent with Munchausen syndrome.

Although Kleine-Levin syndrome has been described after pituitary tumors and thalamic infarction (8), psychic abnormalities including disturbed sleep patterns, excessive sexuality, abnormal eating patterns and loss of recent memory are common in hypothalamic disease and in pituitary tumors (9-12). In acromegaly personality changes such as diminished libido (13), lethargy, failing memory (14), frequent mood changes, episodes of depression, irritability, restlessness, egocentricity, loss of motivation $(15,16)$ have been described. On the other hand, no increase in psychiatric morbidity has been shown in acromegalic patients (17).

Concerning the side effects of radiation therapy, most patients with post radiation necrosis, which develops chiefly in the temporal lobe (18), are asymptomatic. However, if clinical manifestations occur, impairment of mental function is the most prominent feature (19).

However, treatment with bromocriptine, which is structurally related to dopamine, has been shown to be 
associated with psychotic reactions (20). Whereas these side effects are very common at daily doses greater than $20 \mathrm{mg}$ they can also occur in patients receiving lower doses (21).

Many acromegalic patients have the obstructive sleep apnea syndrome due to macroglossia and hypertrophy of hypopharyngeal tissues, which includes excessive daytime sleepiness (22) and apneic episodes during sleep (23).

Although some of the psychiatric disorders of our patient such as the abnormal eating pattern and depressive mood are typical of acromegalic patients, the Munchausen syndrome, sleeping attacks over $20 \mathrm{~h}$ and increased libido in this case do not fit with the features described above, so that the Kleine-Levin syndrome as a concomitant illness seems more likely. Furthermore, the symptoms do not seem to be typical of the psychiatric side effects of bromocriptine.

In conclusion we describe an unusual course of recurrent acromegaly, accompanied by a Kleine-Levin syndrome that developed 10 months after single field radiation therapy and Munchausen syndrome. The residual growth hormone-producing tumor has - so far - not expanded further under bromocriptine/ somatostatin analog treatment. The secondary pituitary dysfunction still requires hormone replacement therapy with which the patient has so far complied.

It remains unclear whether the neurological and psychiatric abnormalities result from the acromegaly, the remaining tumor, the post-radiation necrosis of the temporal lobe or whether they are purely coincidental.

\section{References}

1 Asher R. Munchausen syndrome. Lancet 19511 339-341.

2 Zahner J \& Schneider W. Munchausen syndrome in hematology: case reports of three variants and review of the literature. Annals of Hematology 199468 303-306.

3 Putnam FW, Guroff JJ, Silberman EK, Barban L \& Post RU, The clinical phenomenology of multiple personality disorder: 100 recent cases. Journal of Clinical Psychiatry $198647285-$ 293.

4 Toth EL \& Baggaley A. Coexistence of Munchausen's syndrome and multiple personality disorder: detailed report of a case and theoretical discussion. Psychiatry 199154 176-183.
5 Badino R, Caja A, Del Conte I, Guida C \& Ivaldi M. Kleine-Levin syndrome in an 82-year-old man. Italian Journal of Neurological Sciences 199213 355-356.

6 Kluft RP. Treatment of multiple personality disorder. Psychiatric Clinics of North America 19847 9-29.

7 Spiegel D. Multiple personality as a posttraumatic stress disorder. Psychiatric Clinics of North America 19847 101-110.

8 McGilchrist I, Goldstein LH, Jadresic D \& Fenwick P. Thalamofrontal psychosis. British Journal of Psychiatry 1993163 113-115.

9 Martin JB, Reichlein S \& Brown GM. Clinical Neuroendocrinology, edn 2. Philadelphia: FA Davis, 1987.

10 Krieger DT. The hypothalamus and neuroendocrine pathology. In Neuroendocrinology, pp 13-22. Eds DT Krieger \& JC Hughes. Sunderland, MA: Sinauer Associates, 1980.

11 Morgone PJ \& Panksepp J. The Handbook of the Hypothalamus. Behavioural Studies of the Hypothalamus, vol 3, parts A and B. New York: Marcel Dekker, 1980, 1981.

12 Spence SA, Taylor DG \& Hirsch SR. Depressive disorder due to craniopharyngeoma. Journal of the Royal Society of Medicine 1995 $88637-638$.

13 Jadresic A, Banks LM, Child DF, Diamant L, Doyle FH, Fraser TR et al. The acromegaly syndrome. Relation between clinical features, growth hormone values and radiological characteristics of the pituitary tumours. Quarterly Journal of Medicine 198251 189-204.

14 Beumont PJV. Endocrines and psychiatry. British Journal of Hospital Medicine 19727 561-579.

15 Labhart A. Clinical Endocrinology. New York: Springer, 1974.

16 Bleuler M. The psychopathology of acromegaly. Journal of Nervous and Mental Disease 1951113 497-511.

17 Abed RT, Clark J, Elbadawy MH \& Cliffe MJ. Psychiatric morbidity in acromegaly. Acta Psychiatrica Scandinavica 198775 635-639.

18 al-Mefty O, Kersh JE, Routh A \& Smith RR. The long-term side effects of radiation therapy for benign brain tumors in adults. Journal of Neurosurgery 199174 502-512.

19 Valk PE \& Dillon WP. Radiation injury of the brain. American Journal of Neuroradiology 199112 45-62.

20 Turner TH, Cookson JC, Wass JAS, Drury PL, Price PA \& Bresser GM. Psychotic reactions during treatment of pituitary tumours with dopamine agonists. British Medical Journal 1984 289 1101-1103.

21 Pearson KC. Mental disorders from low-dose bromocriptine. New England Journal of Medicine 1981305 173-176.

22 Rosenow F, Reuter S, Deuss U, Szelies B, Hilgers RD, Winkelmann W et al. Sleep apnoea in treated acromegaly: relative frequency and predisposing factors. Clinical Endocrinology 1996 45 563-569.

23 Pekkarinen T, Partinen M, Pelkonen R \& Iivanainen M. Sleep apnoea and daytime sleepiness in acromegaly: relationship to endocrinological factors. Clinical Endocrinology 198727 649-654.

Received 25 October 1998

Accepted 2 November 1998 